\title{
JOURNAL.RU
}

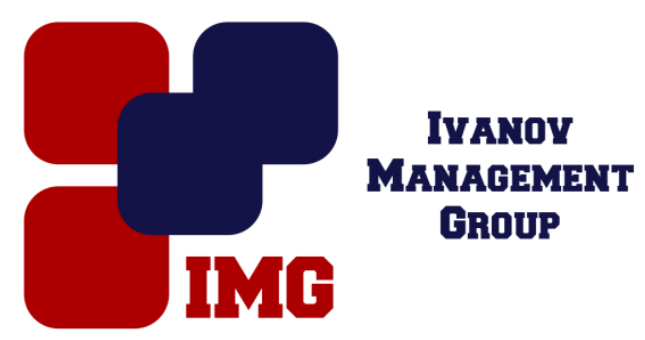

Машкина Е.С., Сапронова С.Г. Курский государственный университет Курск, Россия

doi: $10.18411 / 1 \mathrm{j}-31-05-2017-26$

idsp 000001:1j-31-05-2017-26

\section{Применение информационно-коммуникативных технологий на уроках} биологии

Аннотация
В данной статье рассматриваются вопросы, которые касаются использования информационно - коммуникативных технологий на уроках биологии. Именно информационные технологии, могут оказать большую помощь в подготовке ученика к жизни в информационном обществе и сделать более эффективной учебно-педагогическую деятельность.

Ключевые слова: информационно - коммуникативные технологии, реализация информативно-коммуникативных технологий, процесс обучения.

Модель навыков учеников 21 века отражена через систему ключевых компетенций, сформированность которых позволит ему стать востребованным в современном мире. Развитие информационно-образовательной среды как условие формирования ключевых компетенций субъектов образовательного процесса в условиях профильной школы направлена на решение вопросов преобразования школы, внедрения новых подходов и методов в процессы обучения и преподавания, где одним из действенных инструментов, способных осуществить взаимосвязь трех аспектов обучения: технологических знаний, предметных и педагогических знаний, выступает ИКТ.[1]

Технологическая культура учителя и ученика, как сообщающийся сосуд, но учитель остается организатором учебного процесса, формирует познавательную активность учащихся. Использование инновационных образовательных технологий является обязательным условием обучения 
современного школьника, его интеллектуального, творческого, нравственного развития.

При использовании информационно - коммуникационных технологий на уроке биологии учителя придерживаются следующих правил: весь использованный инструментарий должен быть направлен на эффективное изучение школьного материала, а также максимально способствовать активизации мыслительной деятельности учащихся, реализации их творческого потенциала.

На сегодняшний день школы имеют все условия для эффективной реализации информационно-коммуникативных технологий на уроках биологии: создано информационно-образовательное пространство, установлена локальная сеть с выходом в интернет; педагогам и учащимся обеспечен свободный доступ к рабочему месту, оборудованному компьютером, создан банк образовательных ресурсов в виде тестов, проектов, контрольно-измерительных материалов, разработок уроков. На своих уроках учителя используют слайдовые презентации, аудио и видеоматериалы, электронные учебники, прибегают к возможности использования интернет-ресурсов. В ходе проведенного нами опроса учителей городских и районных школ нами были получены следующие данные.60\% учителей согласились, что их учебные заведения оснащены компьютерным оборудованием, 40\% ответили, что их школы недостаточно им оснащены. Опрошенные учителя подтвердили, что они активно пользуются компьютерными средствами. Так 53\% педагогов используют ИКТ ежедневно, 40\% применяют 1-2 раза в неделю и только 7\% респондентов практикуют информационные технологии 2-3 раза в месяц (рис.1).

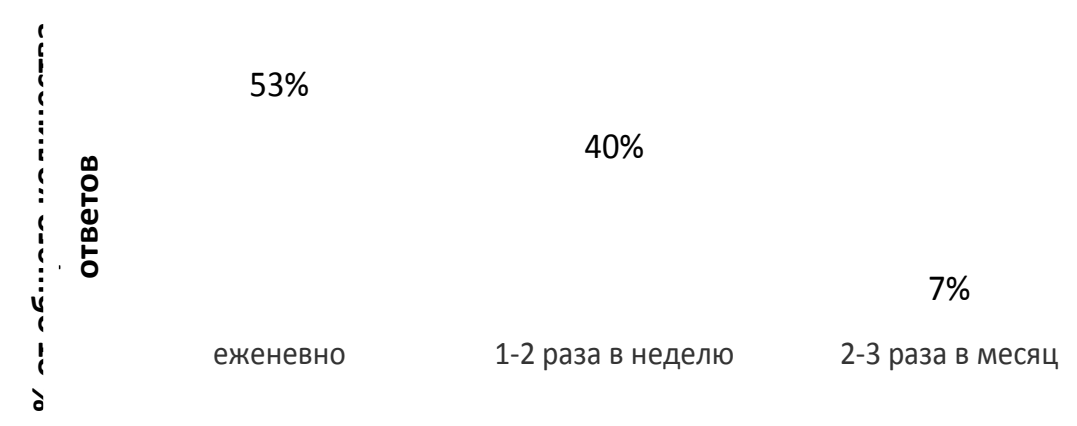

Рис.1. Частота использование информационно-коммуникативных технологий на уроках

Опрошенные учителя единогласно (100\%) считают, что использование информационно-коммуникативных технологий позволяет разнообразить уроки. 
Использование ИКТ помогает повысить интерес школьников к изучаемому предмету, рассеивает ученические страхи, враждебную настороженность и нежелание отдельных учеников работать. Часто используем «оживающие картинки», которые дают возможность продемонстрировать какой-либо динамический процесс, тем самым позволяют приблизиться к реальному восприятию. Таким образом, изучаются, например, темы «Деление клетки: митоз, мейоз».

Широко используются возможности интерактивной доски на этапе закрепления пройденного материала. Например, при работе с немыми карточками, учащиеся должны расшифровать «немой рисунок», в котором присутствуют только цифровые обозначения.

Умение учащихся работать с информационными ресурсами способствует повышению навыков исследовательской деятельности, что дает возможность развивать научное мировоззрение, являющееся необходимым навыком будущих студентов.

Широкое использование электронных вопросов в тестовой форме позволяет оперативно проверить знания, умения и навыки учащихся, а разнообразие применяемых тестовых оболочек повышает обучающий эффект, эмоционально окрашивает задания.

Не секрет, что «единственный путь, ведущий к знанию, - это деятельность» (Бернард Шоу), поэтому широко используем ИКТ при организации самостоятельной работы учащихся в урочной и внеурочной деятельности: включаются творческие задания, которые выполняются с помощью компьютерной поддержки.

Педагог, умеющий рефлексировать собственную деятельность и деятельность учащихся, однозначно отметит, что применение ИКТ оправдано, так как позволяет активизировать деятельность учащихся, дает возможность повысить качество образования учащимся, повысить профессиональный уровень педагога, разнообразить формы межличностного общения всех участников образовательного процесса. Главным результатом использования ИКТ на уроках считается развитие навыков информационного общения, самостоятельности, творческого подхода к привычному. Сформированная информационная компетентность останется достоянием учеников при выходе из школы. 
1. Гузеев В. В. Образовательные технологии ХХІв: деятельность, ценность, успех./-М.: Центр «Педагогический поиск», 2014. - с.96

2. Косторных Ю. А. Внедрение инновационных технологий и применение ИКТ на уроках биологии / Ю. А. Косторных // Актуальные вопросы современной педагогики: материалы III междунар. науч. конф. (г. Уфа, март 2013 г.). — Уфа: Лето, 2013. — С. 169-171.

3. Никишина И. В. Инновационный образовательные технологии и организация учебновоспитательного и методического процессов в школе. //Интерактивные формы методического обучения.-Волгоград: Учитель, 2010.-c.145-147 